\title{
Starting Torque Reduction of Direct Torque Control Based Synchronous Motor Using Simulated Annealing
}

\author{
Amir Hamzah Pohan ${ }^{1)}$, Lady Diana Warpindyastuti²) \\ ${ }^{1}$ Fakultas Teknik, Universitas Tama Jagakarsa \\ email: amirhamzahpohan@gmail.com \\ ${ }^{2}$ Fakultas Teknologi Informasi, Universitas Bina Sarana Informatika \\ email: 1ady.1wd@bsi.ac.id
}

\begin{abstract}
The motion control of a container port on an industrial conveyor involves non-linear movement by varying the speed of the conveyor. The stability control of the conveyor system is in the starting current or starting torque of the synchronous motor. The starting performance of the motor requires rapid dynamics and precise regulation, hence the need of a direct control is becoming an urgent demand. A non-linear movement for the starting current of the motor can be effectively controlled through simulation. A synchronous motor is usually specified when constant speed and the power factor correction is required. However, subject to many loads, the starting current and starting torque heat up the fuse of the armature rotor and stator. Full state feedback control through simulation has been shown as not being able to stabilize a conveyor movement. Therefore, the need for direct control is important to stabilize the system. The starting current at a synchronous motor should be able to perform better, even for cases where the controlling parameter model was uncertain or changing over time. A reference of any controller model will be selected to stabilize the non-linear motion of the motor. Then the simulation studies will be performed to observe the performance with any controller on starting current of motor. A one objective simulated annealing will be used to optimize the system in decreasing a starting current synchronous motor.
\end{abstract}

Keywords: A synchronous motor, Non linear, one objective simulated annealing, starting torque, parameter model

\begin{abstract}
Abstrak
Kontrol gerakan port kontainer pada konveyor industri melibatkan gerakan non-linier dengan memvariasikan kecepatan konveyor. Kontrol stabilitas sistem konveyor berada pada arus start atau torsi awal motor sinkron. Performa start motor membutuhkan dinamika yang cepat dan regulasi yang tepat, oleh karena itu kebutuhan akan kontrol langsung menjadi tuntutan yang mendesak. Gerakan non-linier untuk arus start motor dapat dikontrol secara efektif melalui simulasi. Motor sinkron biasanya ditentukan ketika kecepatan konstan dan koreksi faktor daya diperlukan. Namun, tunduk pada banyak beban, arus awal dan torsi awal memanaskan sekering rotor dan stator dinamo. Kontrol umpan balik keadaan penuh melalui simulasi telah terbukti tidak mampu menstabilkan gerakan konveyor. Oleh karena itu, kebutuhan pengendalian langsung menjadi penting untuk menstabilkan sistem. Arus start pada motor sinkron harus dapat bekerja lebih baik, bahkan untuk kasus di mana model parameter pengontrol tidak pasti atau berubah seiring waktu. Referensi model pengontrol apa pun akan dipilih untuk menstabilkan gerakan
\end{abstract}


non-linier motor. Kemudian studi simulasi akan dilakukan untuk melihat performansi dengan pengontrol apapun pada arus start motor. Sebuah anil simulasi satu objektif akan digunakan untuk mengoptimalkan sistem dalam mengurangi motor sinkron arus start.

Kata kunci: Motor sinkron, Non linier, anil simulasi satu obyektif, torsi awal, model parameter.

\section{INTRODUCTION}

A conveyor system is used to move and transfer heavy objects either continuously or discontinuously especially in the heavy industry [Ghazi Abu Taher, 2012]. The main function of a good movement machine plane is distributing materials and working equipment in a horizontal direction. Operational performance characteristics of a conveyor plane include starting current, starting torque, acceleration and braking. The conveyor plane is the part that is used continuously and has a direct connection with the electric motor as shown in figure-1.

In first, the electric motor used to lift goods was a dc motor. The dc motor is called primary motor with a field current and armature current that can be controlled separately in a high speed [S. Mehta,2011]. Therefore, it can be controlled without the help of an electronic circuit. A dc motor uses a starting torque to operate at a very high speed, Due to high a starting torque or starting current are high, although the fuse is easily tripped and the armature rotor-stator is very hot.

With developed methods on the field oriented control of induction motors, the load current and current gain can be controlled separately in moving a conveyor. Thus the use of a dc motor are displaced by an induction motor. The advantages of an induction motor is that the construction and maintenance costs are relatively cheaper compared to a dc motor. But the drawback of the most prominent induction motors on a starting current is poor and the characteristic of the induction motor is a large overshoot at start [ M.S. Aspalli, 2012]. So, a tool control is needed for the starting current of induction motor. This uses direct line starting, Y-Delta starting and autotransformer.

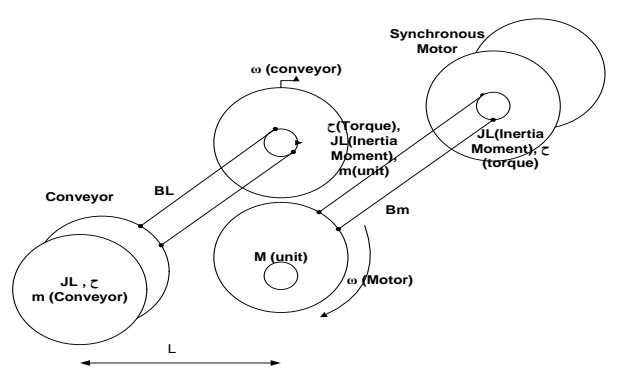

Figure 1 Conversion model of electro - mechanic

One of the typical problems in synchronous motor is to decrease the starting current in a mathematical model of the investigated systems. Most mathematical model algorithms are focused on finding a smooth starting current. Most real engineering system optimization problems are multi-objective in nature, since they have several parameters 
and objectives that must be considered and satisfied simultaneously. The study by Suman and kumar showed that a new algorithm based on multi-objective optimization algorithm for a model structure selection proposed is a multi-objective optimization using simulated annealing [Kumar, 2009] . This research analyses a starting current on synchronous motor using a multi-objective simulated annealing with vector control. Therefore, a line starting current of synchronous motor can be controlled accurately.

In this paper, a simulated annealing method is developed to determine the optimization response and starting torque in the proposed assembled starting current to a synchronous motor. The periodic starting torque and current part in figure- 2 are regarded as signal guides that are sequentially connected to the rotor-stator armature, as shown in figure-3. The stator-rotor armature is modelled by a synchronous motor for transmission a conveyor belt, while starting current guides are modelled by a synchronous motor to start up the computation. In contrast to the aforementioned studies, the starting torque with a synchronous motor modelled characteristic circuit will be kept while the starting current of the current signal guides will be eliminated eventually. The response and starting current of the current signal guides can be obtained by post-processing.
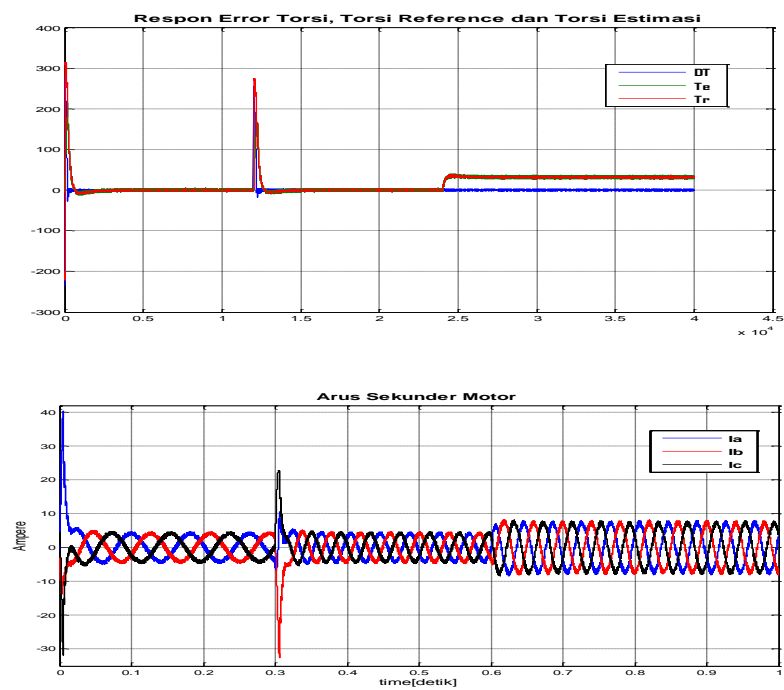

Figure 2 Signal of a starting torque and current

The proposed machine is of the cylindrical rotor design, without taking into consideration the effects of saturation, slotting, eddy current, damper windings, and harmonics. The voltage equations of the machine for the three-phase stator windings and the two rotor windings in the rotor reference frame can be easily in figure- 3 . 


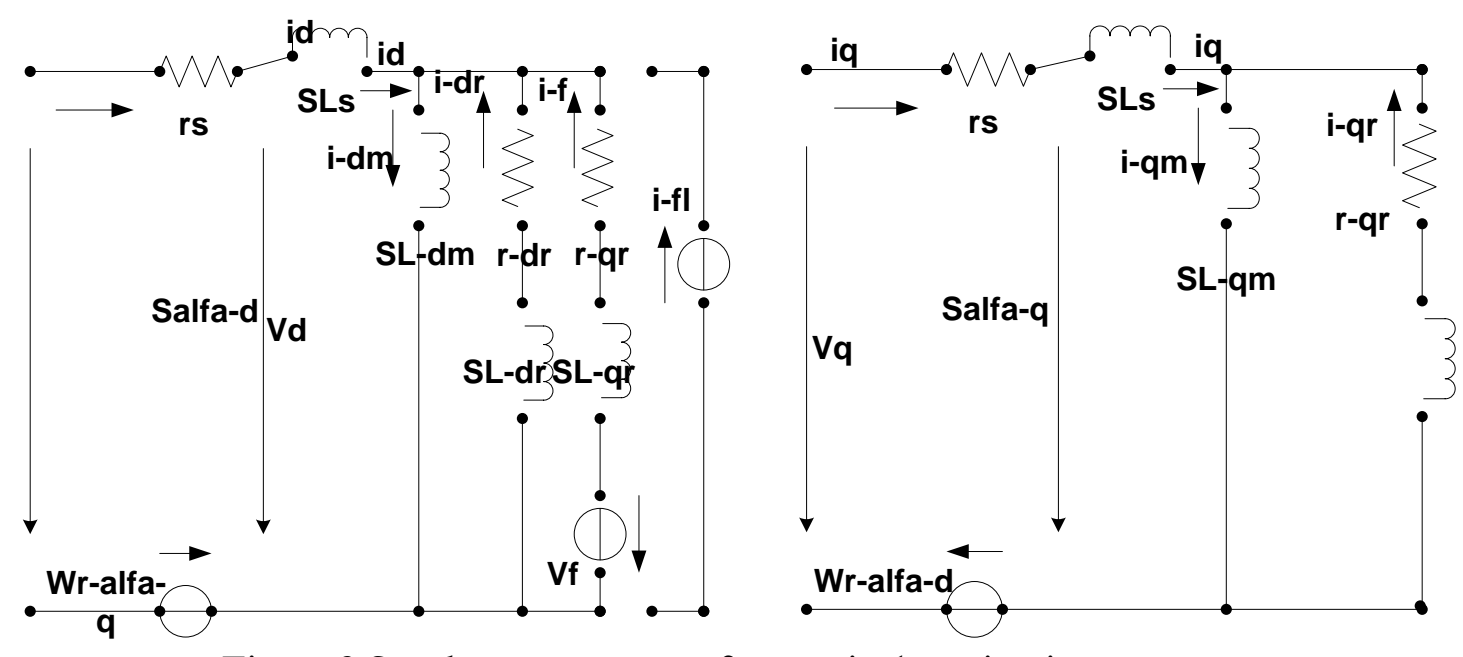

Figure 3 Synchronous motor of an equivalent circuit

The electrical torque produced by the rotor takes in to consideration the interaction offered by these field winding. This is deduced from first principles by writing the equation of the co-energy of this multiply excited coil system and differentiating the resulting equation with respect to the rotor angle $\theta_{r}$. There instantaneous torque equation is transformed to the rotor reference frame and the final torque equation is written as (Amin Mahmoudi,2013):

$$
. T_{e}=1.5 * P * L_{m}\left(i_{f 1} . I_{q}-i_{f 2} \cdot i_{d}\right)
$$

(1)

The equation of motion can be written as:

$$
T_{e}=J *\left(d \omega_{r} / d_{t}\right)+B \cdot \omega_{r}+T_{L}
$$

\section{Mathematical Model of Synchronous Motor}

Development of the machine model through the understanding of physics of the machine is the key requiretment for any type of electrical machine control. For this study, a surface type permanent magnet synchronous motor is used for the investigation model. The development of those models are under the assumptions as below [Ion Boldea,2011]:

(i) A Three-phase motor is symmetrical

(ii) Only a fundamental harmonic of the magneto motive force ( $\mathrm{mmf}$ ) is taken in to account

(iii) The spatially distributed stator and rotor winding are replaced by a concentrated coil

(iv) A isotropy effects, magnetic saturation, iron losses, and eddy currents are not taken into consideration

(v) The coil resistance and reactance are assumed to be constant

(vi) In many cases, especially when it is considered steady state, the currents and voltages are assumed to be sinusoidal

(vii) The thermal effect for permanent magnets are omitted

The synchronous motor model will be presented in space vector notation. This notation is very useful especially, when the analysis of the vector control are based on the technique

\section{http://jurnal.umt.ac.id/index.php/it/index}


of the AC machines. The space vector representation of the $\mathrm{AC}$ machine equations has been discussed in detail in a number of text books [Katalin Vincze,2011].

\section{Direct Torque Control}

The name direct torque control is delivered by the fact that, on the basis of the errors between the reference and the estimated values of torque and flux, it is possible to directly control the inverter states without an inner current control loop as the vector control. The basic idea of this control on stator voltage vector equation of AC motor [Gunawan Dewantoro,2011].

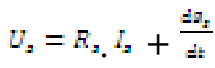

Making the assumption that the ohm voltage drop on the stator resistor can be neglected, the equation for stator flux vector takes the form:

$\sigma_{x}=\int\left(U_{2}\right)$ dite

It can be said that the stator voltage vector has directly influence the control stator flux vector. Using a three phase voltage source inverter to supply the AC motor, there are six non-zero vectors and two zero voltage vectors.

\section{Simulated Annealing}

As mentioned earlier, the Archived One Objective Simulated Annealing algorithm is based on the principle of Simulated Annealing [Wu Zhihong,2011]. In this research, at a given Torque $(\tau)$, a new state $s$ is selected with the probability

$$
\mathrm{P}_{\mathrm{q}}=1 /-(\mathrm{V}(\mathrm{q}, \delta)-\mathrm{V}(\mathrm{s}, \delta)
$$

Where $q$ is the current state and $V(s, 0)$ and $D^{(q, 0)}$ are the corresponding energy values of $s$ and $\mathrm{q}$, respectively. Note that the above equation automatically ensures that the probability value lies in between 0 and 1. The Archived Multi Objective Simulated Annealing incorporates the concept of an Archive where the non dominated solution seen so far are stored. In (5), the use of an unconstrained Archive size to reduce the loss of diversity is discussed in detail. In our approach, we have kept the archive size limited since only a limited number of well distributed Pareto-Optimal solutions are needed. Two limits are kept on the size of the Archive: a hard or strict limit denoted by Hard Law, and a soft limit denoted by Slow Law. During the process, the non-dominated solutions are stored in the archive as when they are generated until the size of the Archive in creases to Slow Law. Thereafter, if more non dominated solutions are generated, these are added to the archive, The size of the switch is thereafter reduced to Hard Law by applying clustering.

\section{METHODOLOGY}

In the proposed model an intelligent combination of PI-DTC controller, tap input and a multi-objective optimization approach is proposed. Figure- 4 shows a block diagram of the optimal performance control model, where $K_{\text {sts }}$ and $\mathrm{x}$ are desired and actual position responses respectively. $\varepsilon(t)$ is the system error and $w(t)$ is the control input force. Based 
on the actual displacement and regular displacement responses, simulated annealing finds optimal PI-DTC gains which are proportional to $\mathbb{E}_{\nabla}$ and integral $\mathbb{E}_{\Sigma}$ gains. The control input w(t) can be written as

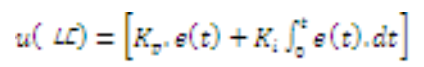

The optimum solution can be obtained using a proper fitness function. In this research, a new fitness function to minimize the sum of absolute error is considered as

$\left.s=\sum_{i=0}^{\pi s}\left\|X_{j}+l_{x} \sin \theta_{j}-X_{d t x}\right\|\right]$

Where $T_{s}$ is the time of simulation, $\mathrm{j}$ is $\mathrm{j}$ - th sample time of the simulation, $\mathbb{Z}_{\mathbb{S}}$ is the absolute value of the position output in the time interval of $\mathrm{j}$, and ${ }^{\theta_{i}}$ is the absolute value of starting in the time interval of $\mathrm{j}$. $\mathrm{S}$ is inspired by the actual position of payload and can be minimized by allocating different values for $E_{\sigma_{*}}$ and $E_{\Sigma}$ based on starting and position formulas in the simulated annealing described in equations (6) and (7). Conceptually, simulated annealing tries to find the optimum gains of PI-DTC controller to have the minimum error signal similar to an experienced operator who can move the conveyor. To simulate the tapped, a new design utilizing delay units, gain units, tap angle, intelligent switch and absolute value block is proposed to produce the tap command for every input automatically. Previously, gain-delay units were utilized to tap a command for non-linear models.

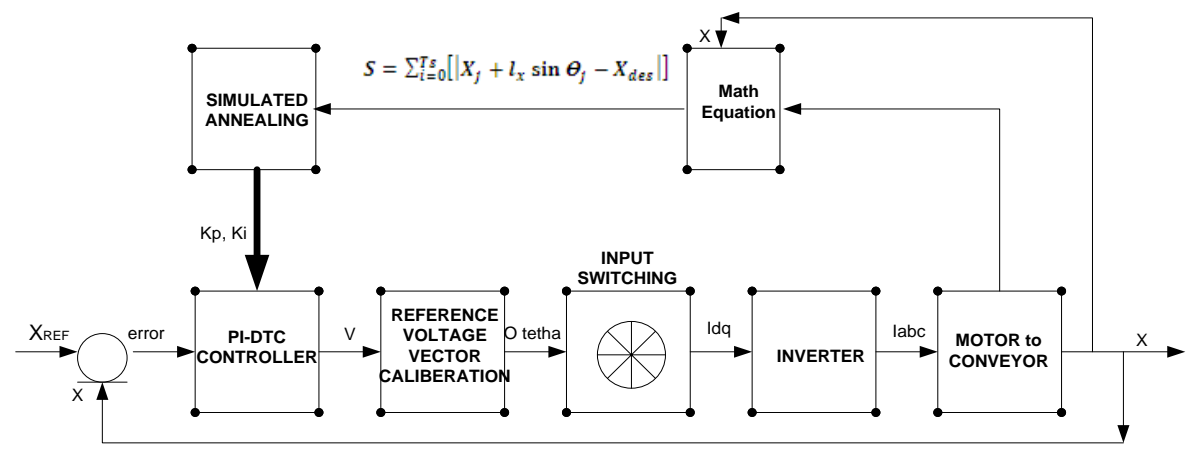

Figure 4 Simulated Annealing tuned PI-DTC control model

\section{RESULTS AND DISCUSSION}

In these results, the control model are implemented and analyzed with the simulation model environment of the conveyor system and the corresponding results are presented. The Simulink is utilized to implement the starting torque and current to a synchronous motor with a conveyor load. The simulation time is set to $10 \mathrm{~s}$ and the fitness function is computed at each iteration until a predefined value of iteration is reached. The PI - DTC - SA controller and optimal performance PI controller are simulated based on the obtained gains to move the conveyor to the starting current position in figure-5. Figure- $6 \mathrm{a}$ and $\mathrm{b}$ show output simulation results of the starting torque and current to $a$ synchronous motor, respectively. It can be shown that the optimal performance of a PIDTC-SA control model needs less effort of an actuator compared to PI-DTC-SA control model. Moreover, the proposed tap-switching design has taped the control signal of a PI 
controller in both falling and rising edges properly. It can be shown that for both starting torque and current, the proposed control model provides better position response performance as compared to a PI-DTC-SA controller. With the proposed controller, the position response showed no overshoot in both directions of the conveyor, lower starting current values, and faster settling time which is nearly half of the PI-DTC-SA controller.

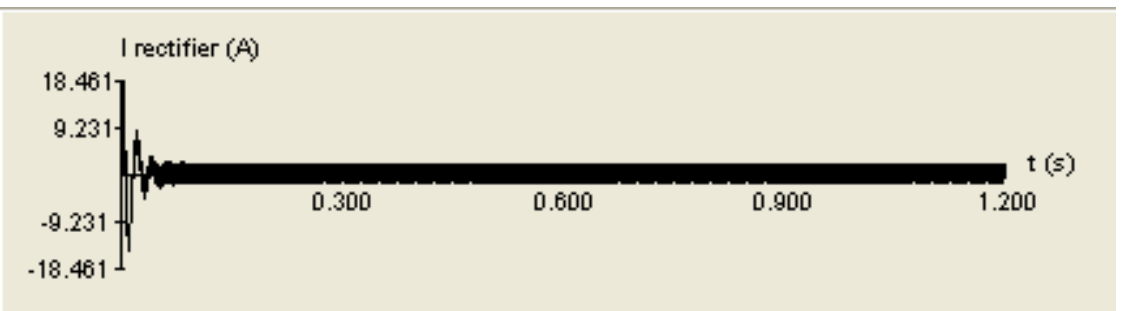

Figure 5 starting torque and current signal control

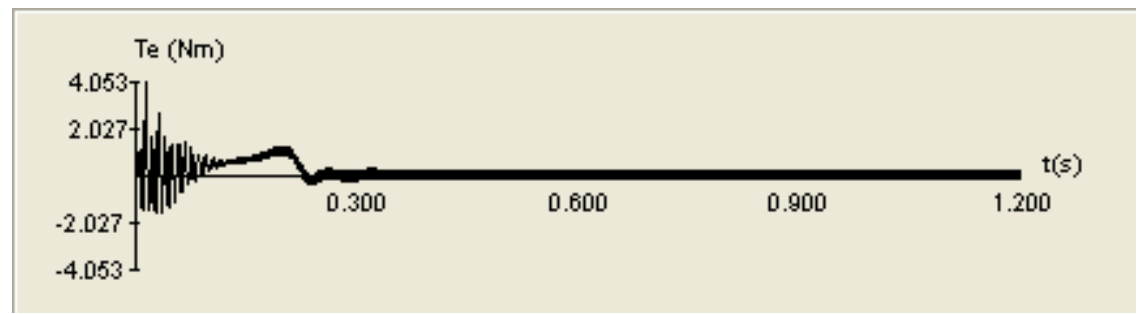

(a) Torque of synchronous motor

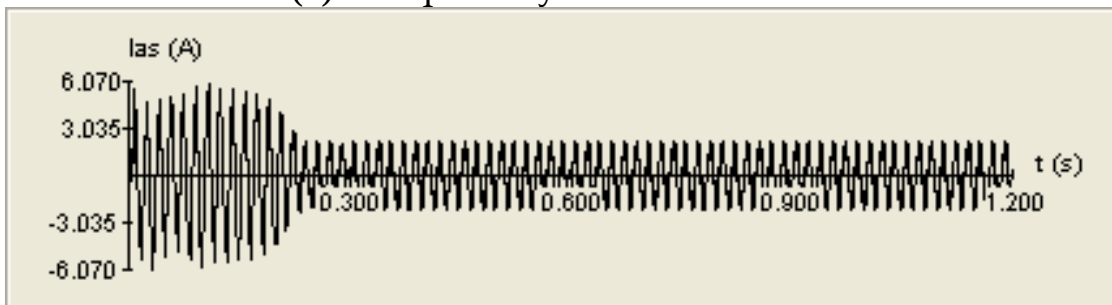

(b) Current of synchronous motor

Figure $6 \mathrm{a}$ and $\mathrm{b}$ Starting torque and current signal output

Table 1 Results of starting a synchronous motor

\begin{tabular}{|c|c|c|c|c|}
\hline No & Method & Speed (Rpm) & Torque (Nm) & Current (A) \\
\hline 1 & $\begin{array}{c}\text { Conventional } \\
\text { direct torque } \\
\text { control }\end{array}$ & 1000 & 2.9 & 6 \\
\hline 2 & $\begin{array}{c}\text { Simulated } \\
\text { annealing } \\
\text { optimization } \\
\text { with direct } \\
\text { torque control }\end{array}$ & 860 & 1.2 & 2.7 \\
\hline
\end{tabular}

An analysis research was performed on a lab-mechanic - electro a conveyor as shown 
in figure-1 to verify the simulation results. The conveyor is equipped with 3 incremental encoders to measure the position of the track in $X$ and $Y$ directions, position of payload in $\mathrm{Z}$ direction, and the payload conveyor in $\mathrm{X}$ and $\mathrm{Y}$ directions. Similar parameters were used in the simulation including input tap switching parameters and controller gains applied to a the conveyor. Figure- $6 \mathrm{a}$ and $\mathrm{b}$ show control signals for the starting torque and current respectively. The results verified that the starting torque and current to a synchronous motor control needs less analysis effort compared to a PI-DTC controller. Moreover, the control signal is smoother. The analysis position responses of both control model for starting torque and current are shown in figure-5 respectively. The results also verified the optimal PI - DTC gives better performance in the position response.

\section{CONCLUSION}

This research presents an simulated annealing to reducing the starting current for synchronous motor with optimization methods. From the simulation results that has been done, it can concluded that :

1. Setting synchronous motor starting torque with a combination of direct torque control ( DTC ) and proportional integrated ( PI ) control have a pretty good dynamic response, It can be seen from the actual torque that follows the conventional torque of the synchronous motor and PI-DTC-SA control with simulated annealing with an efficiency of $96.5 \%$.

2. In direct torque control, inverter switching directly controls the synchronous motor parameters, namely by using the stator voltage feedback control, flux, and torque with forecasts that are controlled by the direct torque control.

3. The optimization losses using simulated annealing to reduce starting torque and current to a synchronous motor with PI - DTC-SA control had an efficiency of $4.1 \%$.

\section{REFERENCES}

Ghazi Abu Taher, Yousuf Howlader, Md. Asheke Rabbi, Fahim Ahmed Touqir," Automation of Material Handling with Bucket Elevator and Belt Conveyor", International Journal of biotech trends and Technology (IJBTT), vol.2, issue-1, number-1, jan.,2012.

R.Krishnan," Electrical Motor Drives: Modeling, Analysis, and Control," four edition, Prentice Hall, 2011.

B.suman and P.kumar," A survey of simulated annealing as a tool for single and multiobjective optimization," J.Oper. Res. Soc, Vol. 57, no.10, pp. 1143-1160, 2009.

Katalin Vincze, Karoly Veszpremi and Balazs ," Adaptive Hysteresis Current Vector Control of Synchronous Motor Drive with Different Tolerance Angle ",Periodica polytechnica El.Eng.Vol.55, No.3-4,pp.312-323, July,2011.

Amin Mahmoudi," Line Start Axial-Flux Permanent Magnet Synchronous Motor", IEEE Transactions, Ind, Appl., Vol. 13, pp.3210-3216, Augst, 2013, University of Malaya2018.

Gunawan Dewantoro," Robust Speed Controlled Permanent Magnet Synchronous Motor Drive using Fuzzy Logic Controller", IEEE International Conference on Fuzzy Systems, June 27-30, 2011, Taipei, Taiwan. 
Khalid I.Saleh," Field Oriented Vector Control of Synchronous Motors with Additional Field Winding", IEEE Transactions On Energy Conversion, Vol. 19,No.1, March 2014.

WU Zhihong, LI Gensheng, ZHU Yuan," Efficient Optimization Control of Permanent Magnet Synchronous Motor Using Artificial Neural Network", Advances in Information Sciences and Service Sciences, Volume 3, Number7, August 2011.

A.Cavagnino,M.Lazzari,F.Profumo,and A.Tenconi,"A Comparison between the Axial Flux and the radial flux structures for PM synchronous Motors," IEEE Transaction on Industrial Application, Vol. 38, No.6,1517- 1524, November=December 2012.

M.S. Aspalli, " Three Phase Induction Motor Drive Using IGBTs And Constant V/F Method ", International Journal Of Advanced Research in Electrical, Electronics and Instrumentation Engineering, Vol. 1, Issue 5, Nov 2012.

Khwaja M. Rahman," Identification of Machine Parameters of Synchronous Motor", IEEE Transaction On Industry Application, Vol.41,No.2,March/Apri;2011.

A Sudhakar1, M Vijaya Kumar," Neural Network Controllers in Direct Torque Controlled Synchronous Motor", International Journal of Power Electronics and Drive System (IJPEDS), Vol.3, No.3, September 2012, pp. 311 320.

T.Bahi, S.Lactar, Y.Soufi, S.Lekhchine, H.Merabet, "Speed Control by Sliding Mode Of Synchronous Motor", Acemp -Electromotion 2011,8-10 September 2011 Istambul, Turkey.

Jaswant Singh, Bindeswar Singh and Sulabh Sachan," Performance Investigation of Permanent Magnet synchronous Motors using vector controlled Technique", International Conference on Power, Control and Embeded System, 2013. 